\title{
ASSESMENT OF TRACE ELEMENTS AND MOBILITY OF ARSENIC AND MANGANESE IN LAGOON SEDIMENTS OF THE HUASCO AND COPOSA SALT FLATS, CHILEAN ALTIPLANO
}

\author{
VENECIA HERRERA* I, IDA DE GREGORI ${ }^{2}$, HUGO PINOCHET ${ }^{2}$
}

\author{
Laboratorio Química Analitica y Ambiental. Departamento de Ciencias Químicas y Farmacéuticas. \\ Universidad Arturo Prat. Avenida Arturo Prat 2150. Iquique, Chile \\ Laboratorio Química Analitica y Ambiental, Instituto de Química; Facultad de Ciencias Básicas y Matemáticas. Pontificia Universidad Católica de Valparaíso, \\ Avenida Brasil 2120, Valparaiso, Chile \\ Received: April 8, 2009 - Accepted: July 22, 2009)
}

\begin{abstract}
Total concentration of $\mathrm{Fe}, \mathrm{Mn}, \mathrm{Zn}, \mathrm{Cu}, \mathrm{Cr}, \mathrm{Cd}, \mathrm{As}, \mathrm{Sb}$ and $\mathrm{Se}$ in lagoon sediments found in the Huasco and Coposa salt flats, Chilean Altiplano and the mobility of As and Mn by means of a simple extraction methodology was studied. The optimum digestion was made with $\mathrm{HCl}_{\mathrm{HNO}} \mathrm{HN}_{3} 3: 1$, and the detection of elements, by means of FAAS, ET-AAS, HG-AAS and HG-AFS techniques.

Sediments contain a high concentration of As, which ranges from 43 to $268 \mathrm{mg} \mathrm{Kg}^{-1}$ but low concentration in the majority of other elements with different proportions depending on the date of sampling. Huasco presented the greater enriched condition and the concentration of Mn was approximately nine times higher.

The greater mobility of As species was obtained in the metalloid's higher accumulation season. The extracting solutions of: 0.11M HOAc; acetate buffer in the ratio of 1 to 50; and, double-phase extraction in the ratio of 1 to 25 , presented the same efficiency. Because of the high concentration of As, it is not possible to obtain the same mobility, when a acetate buffer in the ratio of 1 to 25 is employed. The $100 \%$ quantitative extraction was achieved by using $0.43 \mathrm{M}$ HOAc and a solution of $0.25 \mathrm{M} \mathrm{H}_{2} \mathrm{SO}_{4}$. The removal of As oxalate buffer, depends on the origin and, the content of $\mathrm{Fe}$ and $\mathrm{Mn}$ in the sample. When the oxalate buffer is employed Huasco presented a higher mobility (61 and 67\%) than Coposa (37\%).

Sediments do not present any soluble salts of $\mathrm{Mn}$ in water. The percentage of Mn extracted with $0.11 \mathrm{M} \mathrm{HOAc}$, and any of the other three extracting solutions, is much higher in Huasco. However, when using $0.25 \mathrm{M} \mathrm{H}_{2} \mathrm{SO}_{4}$, this tendency becomes inverted exhibiting less mobility in Huasco (45-88\%) than in Coposa $(63-99 \%)$.
\end{abstract}

Keywords: Salar, Sediments, Trace element, Simple extraction, Arsenic mobility, Manganese mobility

\section{INTRODUCTION}

The geologic unit, known as "highland plateau or Salar Zone", is located in the North of Chile, to the east of the Chilean Andes. Its land is relatively flat and is usually discontinued by new volcanic cones and covered by ignimbrite deposits originated during the Late Tertiary and the Quaternary. The geomorphologic characteristics of this area, located between two mountain ranges, present numerous endorreic basins that eventually form salt flats or lagoons ${ }^{1}$. Huasco salt flat (RAMSAR site) is located in a closed basin under the same name, with various shallow lagoons that present changeable levels of salinity. Coposa salt flat is located nearby south of Huasco salt flat, almost adjacent to Bolivia, and its basin supplies underground water to the copper mining industry, whose average demand is around $600 \mathrm{~L} / \mathrm{s}$. These wetlands and theirs ecosystems maintain a unique biodiversity and are characterized by its flora and fauna endemism².

In aquatic ecosystems, the relevance of the quantity of trace elements and chemical-physical states of some species, is related, first with the circulation and interaction of these elements in each different compartment, and second, to explain their mechanism within the ecosystem and their corresponding living organism $^{3}$. The fluctuation of concentration depends on several factors such as: geographic location, nature, type of soils and the anthropogenic activities carried out nearby. In the North of Chile, the relationship between volcanism activities and the presence of arsenic is a known feature, as well as the relevance of this geological process with the genesis of big copper deposits ${ }^{4}$. This area is affected by the presence of high concentrations of metalloid, which has been attributed to hydrothermal conditions such as geysers and fumaroles in the prerange and high plateau, and where water is contaminated in proportion to its salinity levels ${ }^{5,6}$

Within an aquatic ecosystem, metals and metalloids are distributed among various components: a part of these elements is associated with dissolved ligands, while others, with particulate material, followed by adsorption, precipitation or co precipitation processes or, they can be absorbed by plankton. As a result of a variety of physical, chemical and biological processes, a significant fraction of trace elements is linked to the bottom sediments, and, at the same time, they are distributed in a variety of physicochemical forms ${ }^{7}$. The evidence of trace elements in uncontaminated sediments has been used as a reference for contaminated areas and is considered as a comparative tool for natural water database 8,9 .

The term "speciation" has been used since the 70 's for a wide variety of analyses, ranging from the determination of states of oxidation to the determination of physicochemical forms for each element. Chemical interaction between compounds and species from a sample are defined "functionally" as bio-available or movable species (related to an extraction procedure) and "operationally", according to the reactive or selective dissolution used for the extraction ${ }^{10,11}$.

Simple extraction is carried out to obtain elements associated to a specific phase of the solid matrix and to study the eco-toxicity and metal mobility in soils. In the 90's, methodologies were implemented in order to improve and standardize the quality of the speciation studies dealing with extractable trace metals from soils and sediments, in order to homogenize the results obtained within the European Community. For this purpose, solutions of 0.05M EDTA $\mathrm{pH} 7.0 ; 0.43 \mathrm{M} \mathrm{HOAc}^{12,13}$, as well as $0.11 \mathrm{M} \mathrm{HOAc}$ (interchangeable fraction) were established for the first step of the sequential extraction ${ }^{14,15}$.

The study of sediment composition has an important role in determining chemical patterns in which trace elements can be presented while, on the other hand, when the conditions of these trace elements vary, in studying the transference of the retained chemical species into the aquatic system. Studies on trace element distribution and speciation in high altitude saline ecosystems are not well known. Existing research has been mainly focused on the world's largest salt crust: Uyuni and Coipasa salt flats in the Bolivian Altiplano $0^{6,16,17}$.

The objective of this study was to obtain trustworthy analytical information about concentration levels in metals and metalloids of environmental interest found in lagoon sediments in both Huasco and Coposa salt flats. Due to the high arsenic concentration levels and, the important variations in manganese concentration, it is a matter of interest to evaluate their mobility by using simple extraction methodologies with previously selected solutions whose chemical properties are in accordance with the characteristics for these matrices or, those recommended in specialized literature: water, $1 \mathrm{M}$ acetate buffer $\mathrm{pH} 5.0(1: 25$ ratio and 1:50 ratio; and double extraction); $0.11 \mathrm{M}$ acetic acid and $0.43 \mathrm{M}$ acetic acid, $0.1 \mathrm{M}$ oxalic acid - ammonium oxalate buffer and $0.25 \mathrm{M}$ sulfuric acid.

The analytical determination of metal and metalloid concentration in environmental samples is considered a difficult problem to deal with. Therefore, in order to analyze $\mathrm{Fe}, \mathrm{Mn}, \mathrm{Zn}, \mathrm{Cu}$ and $\mathrm{Cr}$ by means of FAAS; $\mathrm{Cd}$ by means of ET-AAS and As, Sb and Se by means of HG-AAS or HG-AFS it was necessary to improve the preliminary sample treatment, the digestion process and the different analytical techniques regarding atomic spectroscopy. Moreover, it was also necessary to validate the analytical methodology with the reference material for sediment SMR 1646/NBS ${ }^{18,19}$. 


\section{EXPERIMENTAL}

Study area and sampling

The area in which the research was carried out included the lagoons of both Huasco and Coposa salt flats, which are located in the Region of Tarapacá, Chile, near the Bolivian frontier at an altitude of 3800 meters above sea level. Huasco salt flat lies at $20^{\circ} 17^{\prime} 30^{\prime \prime}$ south latitude and $68^{\circ} 52^{\prime} 20^{\prime \prime}$ west longitude. Its surface measures $29 \mathrm{Km}^{2}$ from which estimated that $2.0 \mathrm{Km}^{2}$ is covered by superficial water. A little further to the south $(50 \mathrm{Km})$, Coposa salt flat lies at $20^{\circ} 40^{\prime} 15^{\prime \prime}$ south latitude and $68^{\circ} 42^{\prime} 10^{\prime \prime}$ west longitude, its surface measures $85 \mathrm{Km}^{2}$ and a residue lagoon whose changeable surface is around $5 \mathrm{Km}^{2}$. Both salt flats have permanent saline lagoons where organisms adapt to these extreme conditions ${ }^{6}$.

The annual cycle sampling was carried out in January (Bolivian winter), May, August and December 2000. The four sampling places were selected on two transect (North and South) that cross both salt flats from west to east (sites market with GPS). The symbol used to name the Huasco samples in January is $\mathrm{H} 01$, and C01 refers to Coposa; the same goes for H05 and C05 in May and so on. Waters samples were collected to determine $\mathrm{pH}$, total dissolved solids, as well as ions of sodium, potassium, calcium, magnesium, chloride, sulfates and carbonates. Representative samples of $2 \mathrm{Kg}$ approximately were obtained from shallow sediment $(0-20 \mathrm{~cm}$ deep $)$

Chemical analysis

In order to prevent the contamination, the sediments were placed on a plastic tray and dried at room temperature $\left(24\right.$ to $\left.28^{\circ} \mathrm{C}\right)$. Later, the sediments were sieved on a $63 \mu \mathrm{m}$ mesh, and conserved in a dry sample store. First, the percentage of easily oxidizable organic carbon and calcium carbonates were determined ${ }^{20}$. Then, samples were digested with different mixtures of $\mathrm{HNO}_{3}$ with $\mathrm{HCI}, \mathrm{HF} / \mathrm{H}_{3} \mathrm{BO}_{3}$, in high pressure teflon pumps (PTFS) at $170^{\circ} \mathrm{C}$. The same treatment was simultaneously carried out on the sample, blank solution and reference material (Estuarine Sediment SMR 1646/NBS). Fe, $\mathrm{Mn}, \mathrm{Zn}, \mathrm{Cu}$ and $\mathrm{Cr}$ were determined by means of FAAS; Cd by ET-AAS in a pyrolytic graphite furnace with L'vov platform and adding different mixtures of $\mathrm{NH}_{4} \mathrm{H}_{2} \mathrm{PO} 40 \mathrm{mgml}^{-1}$ and $\mathrm{Mg}\left(\mathrm{NO}_{3}\right) \mathrm{x}_{6} \mathrm{H}_{2} \mathrm{O} 2 \mathrm{mgml}^{-1}$ as modifiers. $\mathrm{As}, \mathrm{Sb}$ and Se were determined by two different techniques: by hydride generation atomic absorption spectrometry (HG-AAS), using a GBC 905 AA Atomic Absorption equipment, that includes a flame and electro-thermal graphite furnace atomization (model GF 3000) and an automatic sampler (PAL 3000); and by hydride generation atomic fluorescence spectroscopy (HG-AFS), using a PS Analytical Atomic Fluorescence equipment model Millennium Excalibur 10055. Both techniques have a FIA system to generate the hydride (model HG 3000).

\section{Extraction procedures}

The functional and operational speciation of arsenic was carried out by simple and double extraction of samples that were extracted with different extracting solutions: water, 1:25 sediment $/ \mathrm{H}_{2} \mathrm{O}$ at $16 \mathrm{~h}$; acetate buffers, 1:25 sediment/1 M NaOAc/HOAc pH 5.0 at 16 h, 1:50 sediment/1M NaOAc/HOAc pH 5.0 and, a double-phase extraction 1:25 sediment/1M NaOAc/HOAc $\mathrm{pH}$ 5.0 at $16 \mathrm{~h}$; acetic acid solutions, $1: 40$ sediment/0.11M HOAc at $16 \mathrm{~h}$ and, $1: 40$ sediment/ $0.43 \mathrm{M} \mathrm{HOAc}$ at $16 \mathrm{~h}$; oxalate buffer, $1: 25$ sediment $/ 0.175 \mathrm{M}$ $\left(\mathrm{NH}_{4}\right)_{2} \mathrm{C}_{2} \mathrm{O}_{4} 0,175 \mathrm{M} / 0.1 \mathrm{MH}_{2} \mathrm{C}_{2} \mathrm{O}_{4}$ at $2 \mathrm{~h}$; and sulfuric acid, $1: 25$ sediment $/ 0.25 \mathrm{M}$ $\mathrm{H}_{2} \mathrm{SO}_{4}$ at $16 \mathrm{~h}$.

Aliquots of $0.8-1.0( \pm 0.0001) \mathrm{g}$ of dry sediment $(<63 \mu \mathrm{m})$, were added to the corresponding volume of extracting solution. Mixtures were stirred at $150 \mathrm{rpm}$ in a mechanical shaker (Junior Orbital Shaker), at room temperature during a time span of 2 to 16 hours. Later, the extracts were centrifuged (Kubota $1720)$ at $12000 \mathrm{rpm}$, during 20 minutes. The supernatant was decanted and filtered through a filter paper (Advance 2, pore side 5-10 $\mu \mathrm{m}$ ). The extract was conserved at $4^{\circ} \mathrm{C}$ in a small polythene bottle, until the quantification of As by means of HG-AFS, Millenium Excalibur 10055 and Mn by means of FAAS.

\section{RESULTS AND DISCUSSION}

Sediment-water Characteristics

The salinity is expressed as total dissolved solid (TDS) and presents significant temporary variations, with the highest concentration of solutes during May and August (Table 1). During the Bolivian winter season a decrease of salinity is expected due to rains and a corresponding dilution of solutes. In dry season at both salt flats there is a predominance of $\mathrm{Na}^{+}$and $\mathrm{Cl}^{-}$over $\mathrm{SO}^{2-}$ ions. The lagoons are buffered to an average $\mathrm{pH} 8.7 \pm 0.1$, which is independent of the season. The sediments contain a high concentration of calcium carbonate, which are almost independent from the fluctuation of ionic composition of the waters that cover them (Table 2), is explained by considering the extended periods of high evaporation rate which the highland ecosystems are exposed, and because the calcite is usually one of the first minerals that precipitate during water evaporation ${ }^{16}$. Oxidisable organic matter ranging from 1.1 to $1.6 \%$ was similar in both salt flats and presented no temporary variations. The limited quantity in these superficial ecosystems can be related to the presence of a refractory organic fraction which is resistant to oxidation with dichromate. For example, diatoms, unicellular seaweeds which have an organic origin and are included among biogenic siliceous sediments, normally associated to lagoon sediments and volcanic events ${ }^{1,16}$.

In order to determine concentration of trace metals, digestion of the sediments was achieved by using a mixture of $\mathrm{HCI}: \mathrm{HNO}_{3} 3: 1$. However, during validate of the selected method by analyzing the "Estuarine Sediment SRM 1646 " with this mixture, it was not possible to recover the total concentration of elements. This would be due to the resistant silicates inside the matrix, which were completely dissolved when using a mixture of $\mathrm{HCl}-\mathrm{HNO}_{3}-\mathrm{HF} /$ $\mathrm{H}_{3} \mathrm{BO}_{3}$, showing similar concentrations in comparison with the certified element concentrations ${ }^{20}$ (Table 2). In Huasco, most of trace elements present high levels in comparison with Coposa. According to hydrological conditions there are slight temporary variations. When comparing concentration levels summarized by Bowen ${ }^{21}$; Fe presented values lower than limestone and other types of sediments, which generally exceed by a margin of $3 \%$. However, in an environmental study on sediments at a salt lake in Australia (Macquarie lake), a $0.78 \%$ of $\mathrm{Fe}$ pseudo total was determined ${ }^{22}$. Concentrations of $\mathrm{Mn}$ and $\mathrm{Cr}$ were also lower than the rank reported by Bowen; $\mathrm{Zn}$ and $\mathrm{Sb}$ were close to the reported average, while in the case of $\mathrm{Cu}$ it was slightly higher. In both salt flats, the concentration of arsenic is higher and presents a significant increase during the high evaporation season. Concentrations of Mn are nine times higher in Huasco. This confirms that these ecosystems are highly fragile and that their values can be considered as a baseline for future environmental studies. The different contents of metal and metalloids in basin bedrock, from which sediments partially derive as well as the distinct transport and element reactivity phenomena from other compartments, are the source that explain that sediments found in Huasco lagoon are enhanced with many elements in varied proportions.

Sediment behaves both salt flats as a concentrator and receiver matrix of arsenic. Natural increase in a dry season can be explained by the adsorption of $\mathrm{HAsO}_{4}^{2}$, to $\mathrm{pH}$ alkaline and oxidizing conditions, from water or particulate material on carbonate minerals and iron and manganese oxides within sediments ${ }^{7}$. The most abundant carbonates, limestone $\left(\mathrm{CaCO}_{3}\right)$ and dolomites $\left(\mathrm{MgCO}_{3} \mathrm{CaCO}_{3}\right)$, have an influence on $\mathrm{pH}$ and reactivity of trace elements, because trace metal cations and $\mathrm{HPO}_{4}{ }^{2-}$ and $\mathrm{HAsO}_{4}{ }^{2-}$ anions can co precipitate with carbonates, incorporating them in their structure or being adsorbed by both the limestone and the Fe and Mn oxides, all of them being included inside the precipitated carbonates ${ }^{3}$.

\section{Operational and functional speciation of As and Mn}

The study concerning the functional and operational samples during both dry and rainy season was carried out because arsenic has caused serious damage to human health in the North of Chile ${ }^{23,24}$. Different extracting solutions were employed and in some cases the extraction was carried out with the same reactive twice so as to compare and/or increase the extraction efficiency. The methodologies were selected considering the carbonate content in sediments and possible environmental changes that may occur within the ecosystems such as: dryness, recharges, $\mathrm{pH}$ modifications and redox potential of lagoons. In order to compare the extraction results, experimental conditions remained constant and the same methodology for each extract separation was followed (Table 3). The solution $0.11 \mathrm{M}$ HOAc $(1: 40 ; 16 \mathrm{~h})$ is the reactive used in the first stage of the standardized sequence extraction process of $\mathrm{BCR}{ }^{14}$ and $0.43 \mathrm{M}$ HOAc $(1: 40 ; 16 \mathrm{~h})$ solution is the recommended reactive for the evaluation of trace metals that, with the use of acids, are extracted from soils ${ }^{13}$. The results would indicate that it is probable that arsenic is found in the form of arsenite or arsenate.

Matrix neutralization produces a high removal of arsenic when extraction with acetate buffer $1 \mathrm{M} \mathrm{pH} 5.0$ is compared with water (Figure 1). With both extracting solution is possible to observe a higher mobility during the dry season and the rather stable temporary behavior in both ecosystems. 


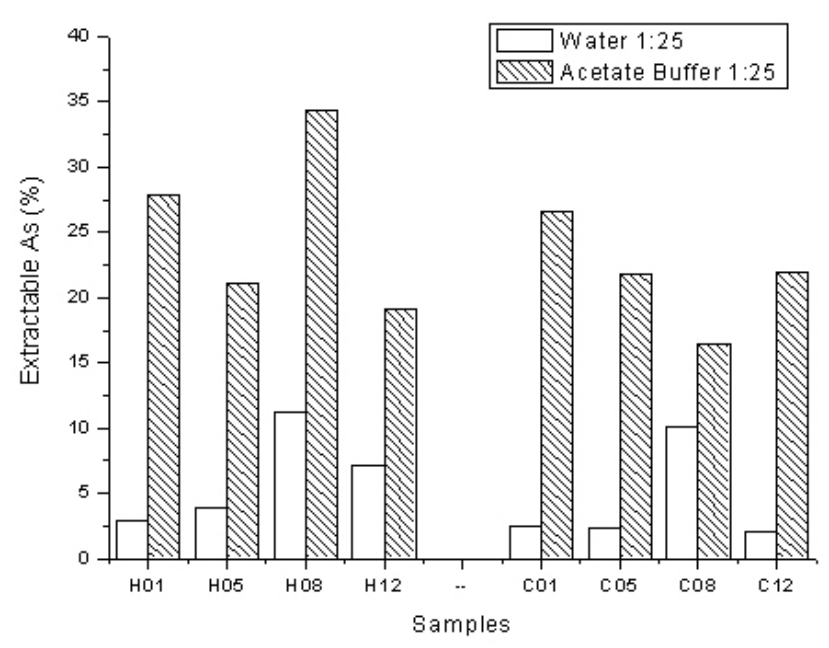

Figure 1: Percentage of extractable As from sediment samples of Huasco and Coposa salt flats by using sediment/water $1: 25$ ratio and sediment/1M acetate buffer 1:25 ratio.

In Figure 2, it show that the percentage of extracted arsenic from Coposa when employing a 1:50 ratio and then a double-phase extraction 1:25, doubles the quantity of extracted arsenic when compared to a one stage arsenic extraction at a ratio of 1:25. It can be observed that in the case of H01 and C08 samples, the percentage of extracted arsenic with $0.11 \mathrm{M} \mathrm{HOAc}$ is slightly higher than the one obtained with acetate buffer $\mathrm{pH}$ 5.0. This could probably be because in sediments, arsenic is linked to calcium which means that in a concentrated media of acetate ion it can create a stable complex with calcium, thus generating the solubilization of the metalloid. However, for sample C01, when arsenic is extracted with the acetate buffer proved to be highly efficient in spite of having the lowest concentration of total arsenic. These differences can be explained considering the total arsenic concentration in samples: in H08, with the highest concentration of total arsenic, a re-adsorption of the metalloid on the substrate can occur.

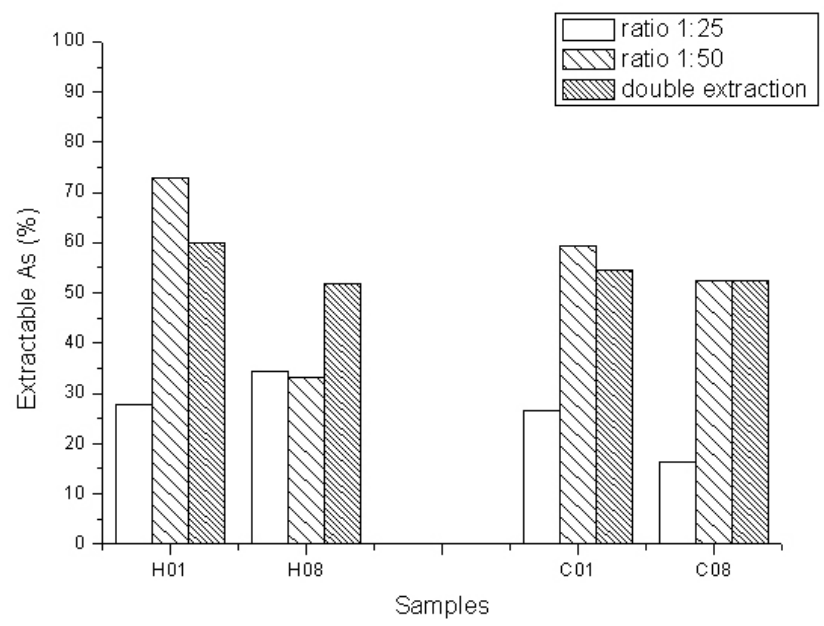

Figure 2: Percentage of extractable As from sediment samples by $1 \mathrm{M}$ acetate buffer, using sediment/buffer 1:25 and 1:50 ratios, and double extraction $1: 25$ ratio.

Figure 3 results show that when using an oxalic acid - ammonium oxalate buffer, removal profiles depend on the location where the samples are taken, and can be explained by the considerable difference of total As and $\mathrm{Fe}$ concentration in these ecosystems. The buffer was selected, because this solution simulates a reducing conditions that may appear in lagoons of salt flats and thus assess the metalloid mobility under these conditions. Soils contaminated with As, employed the above mentioned buffer for simple, triple and sequence-phase extraction procedures in order to determine links between As and $\mathrm{Fe}$ and Al oxyhydroxides ${ }^{25}$. Further, the authors proved that the extractable As is originated from the fraction of amorphous Fe oxides and does not depend on metal contents. On the matter of the adsorption of As on Fe oxides, it has been proved that these compounds, found in soils and sediments, have a tendency to adsorb on its surface As species inserted by anthropogenic environment activities $^{5,26,27}$.In salty lagoons, and although in a very low proportion, the $\mathrm{Fe}$ oxide found in sediments could also be able to adsorb arsenites or arsenates from the waters that cover them. The high percentage of As extracted by means of the oxalate buffer could be due to: the dissolution of carbonates by the effect of $\mathrm{pH}$, and also, to the dissolution of $\mathrm{Fe}$ oxides by reduction and complexation reactions, which can be observed in Figure 4 where the oxalate buffer's slope presents the higher value in comparison with the other three extractants. These results show that under reducing conditions and low $\mathrm{pH}$, the As found in Huasco sediments would present a higher mobility than those in Coposa.

The extraction procedure when using $0.25 \mathrm{M}$ sulfuric acid and $0.43 \mathrm{M}$ HOAc proved that arsenic was quantitatively removed from sediments, with the exception of $\mathrm{H} 08$. The methodology which employed $0.25 \mathrm{M} \mathrm{H}_{2} \mathrm{SO}_{4}$ has been used to fractionate As found in soils by means of a sequence extracting procedure, in which the extracted metalloid is related to calcium ${ }^{26}$. The extraction mechanism assumes the existence of an acid-base reaction between the hydronium ion and the possible weak bases within the sediment (carbonate, borates, arsenites, arsenates). In this way, sulfuric acid extracts arsenic from calcium carbonate or calcium minerals, such as $\mathrm{CaHAsO}$, thus generating insoluble $\mathrm{CaSO}_{4}$. It should be noted that the residue obtained after the sediment extraction (by means of the strong acid) had an intense white coloring, this way proving the formation of precipitated $\mathrm{CaSO}_{4}$.

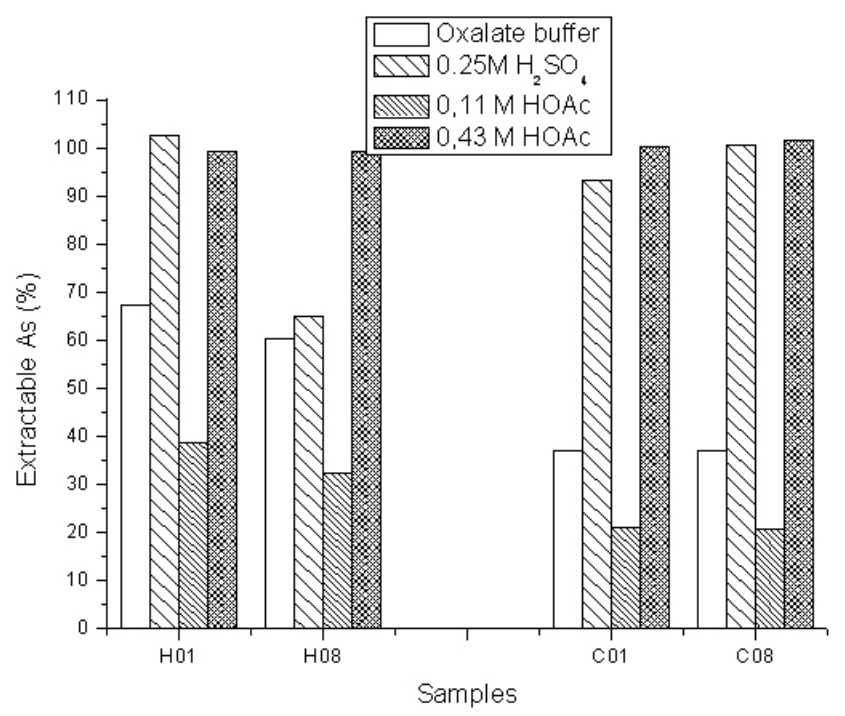

Figure 3: Percentage of extractable As from sediment samples by using buffer oxalate; $0.25 \mathrm{M}$ sulfuric acid; $0.11 \mathrm{M}$ acetic acid and $0.43 \mathrm{M}$ acetic acid.

Figure 4 show that there is a positive linear relationship; water $(\mathrm{r}=$ $0.8870)$, acetate buffer $(r=0.9330)$, oxalate buffer $(r=0.9845)$ and acetic acid $(r=0.9786)$ with the total concentration of As. Consequently, Huasco sediment contains a higher quantity of soluble salts deriving from oxo-anions, which crystallize and remain at the sediment due to a saturation phenomenon in the aquatic environment. When a $1 \mathrm{M}$ acetate buffer $\mathrm{pH} 5.0$ is employed, results show that a decreasing $\mathrm{pH}$ leads to higher levels of arsenic mobility and that mobility will increase when the total concentration increase. This extracting solution would allow to predict changes in the arsenic reactivity when confronted by $\mathrm{pH}$ induced environmental alterations, a fact that has been suggested by different authors in order to establish the association of elements and carbonate fraction ${ }^{12}$. 


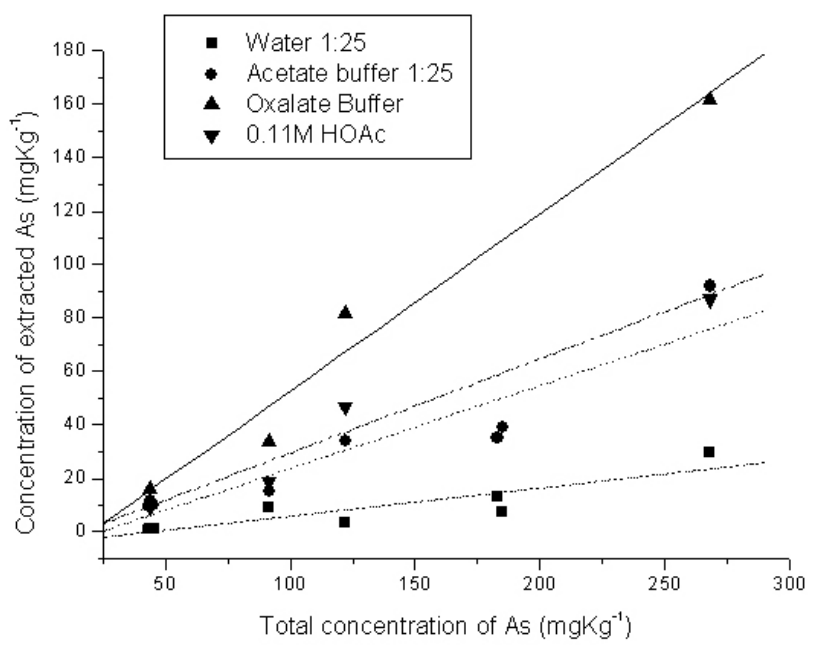

Figure 4. Lineal correlation when compared total concentration concentration of extracted As with: water; acetate buffer; oxalate buffer

Concentration of extracted Mn with different methodologies applied to sediment samples, are shown in Table 4. There is no Mn soluble salt in any ecosystem, when acidity levels increase when increased mobility, and at Huasco it is always grater in the rainy season. The percentage of extractable Mn with $0.11 \mathrm{M} \mathrm{HOAc}$ and any of the three methodologies used with acetate buffer is higher in Huasco (Figure 5). In Coposa, no significant differences were found when using HOAc and acetate buffers 1:25 and 1:50, however, in both ecosystems when a double-phase extraction was applied, the percentage of Mn was higher. At the beginning of the double extraction processes, only a fraction of all the existing carbonates could have been dissolved causing the removal of Mn species associated to this stage. However, it could also be assumed that in the other extracts of acetate buffer (1:25 and 1:50), there would be saturation and, consequently, it would not have the same effectiveness. Mn is extracted in a higher percentage when sulfuric acid is employed which would prove that this solution is able to dissolve not only carbonates but also other sediment components such as insoluble oxides.

The results of functional speciation of manganese in sediments would confirm that in Huasco, a significant fraction (above $10 \%)$ is linked to carbonates, probably as co-precipitated or precipitated of manganese carbonate. Moreover, the highest concentration of total Mn in Huasco, comes from the spring waters of the lagoon, and is deposited in sediments by precipitation phenomena.

The percentages of $\mathrm{Mn}$ extracted with HOAc from the sediments in both salars were lower when $\mathrm{H}_{2} \mathrm{SO}_{4}$ was employed. This can be explained considering the $\mathrm{pH}$-redox potential diagram for $\mathrm{Mn}$ species, because when sediments lie in shallow lagoons with anoxic conditions, some of the $\mathrm{Mn}$ can be found as $\mathrm{MnCO}_{3}$ and as $\mathrm{Mn}(\mathrm{OH})_{2}$. The latter compound was oxidized, probably by the air in the drying process at the laboratory, forming Mn oxides such as $\mathrm{MnO}_{2}$, which is only soluble at very low levels of $\mathrm{pH}$. Therefore, the acidity of the strong acid compared to the weak acid would lead to the removing of the metal in the form of insoluble $\mathrm{MnO}_{2}$. Usually, within the solution of soils or sediments, $\mathrm{Mn}$ only exists as a $\mathrm{Mn}^{2+}$ ion and this species is very mobile at a low redox potential and low pH. Moreover, it is important to mention that the $\mathrm{Mn}^{2+}$ ion can be combined with carbonates and hydroxides in order to form precipitates when the $\mathrm{pH}$ level is higher than 7 , as is the case of the alkaline environment of these lagoons ${ }^{28}$.

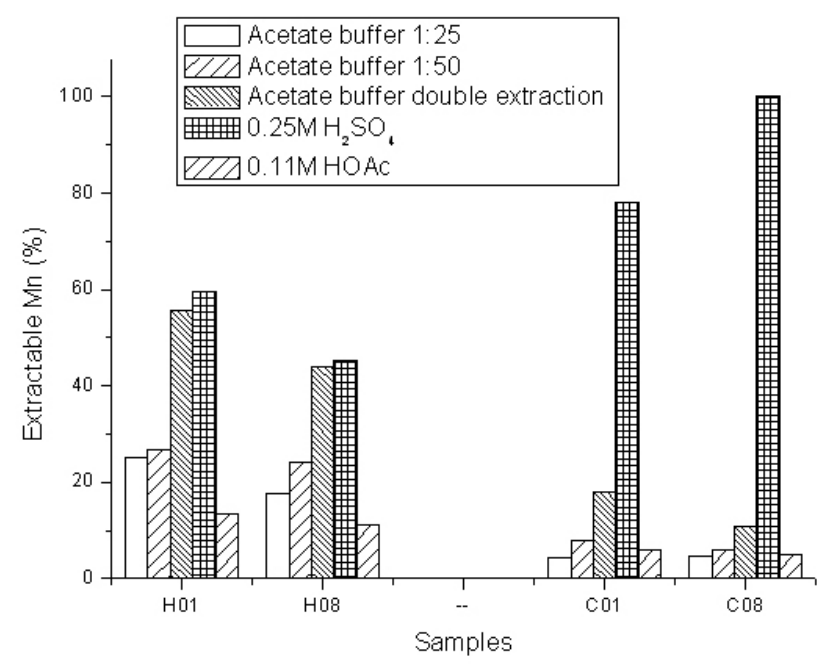

Figure 5: Percentage of extractable $\mathrm{Mn}$ from sediment samples by using sediment/1M acetate buffer in the ratio of 1:25, 1:50 and double extraction 1:25; $0.25 \mathrm{M}$ sulfuric acid and $0.11 \mathrm{M}$ acetic acid. 
Table 1. Chemical properties of the water: $\mathrm{pH}$, TDS $\left(\mathrm{g} \mathrm{l}^{-1}\right)$ and ion concentration (meq $\left.\mathrm{l}^{-1}\right)$ in lagoons of Huasco and Coposa salt flats, Chilean Altiplano.

\begin{tabular}{|l|l|c|c|c|c|c|c|c|c|c|c|}
\hline \multicolumn{1}{|c|}{ Sample } & Date 2000 & $\mathbf{p H}$ & $\mathbf{T D S}$ & $\mathbf{N a}^{+}$ & $\mathbf{K}^{+}$ & $\mathbf{C a}^{\mathbf{}}$ & $\mathbf{M g}^{2+}$ & $\mathbf{C l}^{-}$ & $\mathbf{S O}_{4}^{2-}$ & $\mathbf{H C O}_{3}^{-}$ & $\mathbf{C O}_{3}{ }^{2-}$ \\
\hline H01 & January & 8.61 & $3.5 \pm 0.1$ & 36.2 & 4.1 & 16 & 12 & 33.8 & 26.8 & 1.5 & 0.8 \\
\hline H05 & May & 8.71 & $32 \pm 1$ & 349 & 16.7 & 37 & 168 & 316 & 211 & 1.3 & 10.4 \\
\hline H08 & August & 8.78 & $22 \pm 1$ & 248 & 12.3 & 30 & 113 & 229 & 153 & 1.9 & 6.2 \\
\hline H12 & December & 8.59 & $6.5 \pm 0.2$ & 72.0 & 3.4 & 14 & 66 & 82 & 73 & 3 & 1.3 \\
\hline & & & & & & & & & & & \\
\hline C01 & January & 8.56 & $2.4 \pm 0.1$ & 31.3 & 4.4 & 6 & 4 & 17.9 & 19.3 & 4.7 & 1 \\
\hline C05 & May & 8.65 & $53 \pm 1$ & 656 & 53.8 & 51 & 21 & 80 & 457 & 3.1 & 5 \\
\hline C08 & August & 8.64 & $46 \pm 1$ & 650 & 61.4 & 32 & 42 & 335 & 369 & 4.6 & 3.3 \\
\hline C12 & December & 8.59 & $4.5 \pm 0.2$ & 54.8 & 4.9 & 20 & 12 & 32 & 67 & 4 & 2.1 \\
\hline
\end{tabular}

*: total dissolved solid

Table 2. Concentration of calcium carbonate $(\% \mathrm{wt} / \mathrm{wt})$, organic matter $(\% \mathrm{wt} / \mathrm{wt})$ and total concentration of trace metals (mg kg-1 $\mathrm{dry} \mathrm{wt})$ in sediment lagoons (mean \pm S.D. $n=6$ ) from Huasco and Coposa salt flats, Chilean Altiplano.

\begin{tabular}{cccccccccccc}
\hline Sample & $\mathbf{C a C O}_{3}$ & $\mathbf{O . M}$ & $\mathbf{F e}$ & $\mathbf{M n}$ & $\mathbf{Z n}$ & $\mathbf{C u}$ & $\mathbf{C r}$ & $\mathbf{C d}$ & $\mathbf{A s}$ & $\mathbf{S b}$ & $\mathbf{S e}$ \\
\hline $\mathrm{H} 01$ & $51.1 \pm 0.2$ & $1.46 \pm 0.02$ & $3872 \pm 47$ & $481 \pm 14$ & $22 \pm 1$ & $16.7 \pm 0.3$ & $3.3 \pm 0.1$ & $0.10 \pm 0.01$ & $122 \pm 3$ & $0.37 \pm 0.02$ & $0.19 \pm 0.02$ \\
$\mathrm{H} 05$ & $42.2 \pm 0.7$ & $1.34 \pm 0.06$ & $3638 \pm 65$ & $331 \pm 6$ & $21.8 \pm 0.7$ & $15.7 \pm 0.4$ & $2.7 \pm 0.1$ & $0.12 \pm 0.01$ & $185 \pm 4$ & $0.37 \pm 0.02$ & $0.15 \pm 0.01$ \\
$\mathrm{H} 08$ & $53.3 \pm 0.8$ & $1.46 \pm 0.07$ & $2850 \pm 164$ & $379 \pm 13$ & $17.8 \pm 0.2$ & $19.8 \pm 0.8$ & $2.9 \pm 0.1$ & $0.12 \pm 0.01$ & $268 \pm 3$ & $0.43 \pm 0.05$ & $1.08 \pm 0.05$ \\
$\mathrm{H} 12$ & $49.3 \pm 0.01$ & $1.63 \pm 0.02$ & $3386 \pm 54$ & $398 \pm 30$ & $20.4 \pm 0.4$ & $14.40 \pm 0.08$ & $3.0 \pm 0.1$ & $0.15 \pm 0.01$ & $183 \pm 2$ & $0.31 \pm 0.02$ & $0.39 \pm 0.01$ \\
$\mathrm{C} 1$ & $67.6 \pm 0.8$ & $1.10 \pm 0.1$ & $1446 \pm 26$ & $53.8 \pm 0.1$ & $15.0 \pm 0.2$ & $12.6 \pm 0.4$ & $1.9 \pm 0.1$ & $0.11 \pm 0.01$ & $43.9 \pm 0.4$ & $0.39 \pm 0.4$ & $0.73 \pm 0.01$ \\
$\mathrm{C} 05$ & $64.4 \pm 0.5$ & $1.3 \pm 0.1$ & $2082 \pm 53$ & $54.6 \pm 0.4$ & $17.2 \pm 0.7$ & $5.19 \pm 0.05$ & $2.5 \pm 0.1$ & $0.11 \pm 0.01$ & $45.4 \pm 0.7$ & $0.21 \pm 0.01$ & $0.15 \pm 0.01$ \\
$\mathrm{C} 08$ & $64.1 \pm 0.5$ & $1.52 \pm 0.03$ & $1086 \pm 44$ & $50 \pm 1$ & $13.2 \pm 0.3$ & $12.4 \pm 0.6$ & $1.7 \pm 0.1$ & $0.12 \pm 0.01$ & $91.5 \pm 0.9$ & $0.51 \pm 0.02$ & $1.08 \pm 0.05$ \\
C12 & $55.7 \pm 0.9$ & $1.54 \pm 0.07$ & $1922 \pm 20$ & $48.2 \pm 0.4$ & $13.1 \pm 0.4$ & $7.18 \pm 0.09$ & $2.7 \pm 0.1$ & $0.12 \pm 0.01$ & $43.2 \pm 0.4$ & $0.10 \pm 0.01$ & $0.39 \pm 0.01$ \\
CMR & & & $2.79 \pm 0.02$ & $286 \pm 8$ & $93.0 \pm 0.8$ & $16.5 \pm 0.1$ & $31 \pm 1$ & - & $3.5 \pm 0.1$ & - & - \\
CMR* & & & $3.2 \pm 0.1$ & $315 \pm 3$ & $134 \pm 2$ & $17.8 \pm 0.2$ & $77 \pm 3$ & $0.28 \pm 0.03$ & $12.5 \pm 0.2$ & - & $0.55 \pm 0.05$ \\
CMR** & - & - & $3.35 \pm 0.10$ & $375 \pm 20$ & $138 \pm 6$ & $18 \pm 3$ & $76 \pm 3$ & $0.36 \pm 0.07$ & $11.6 \pm 1.3$ & $(0.6)$ & $(0.4)-$ \\
\hline
\end{tabular}

CMR: Reference material treated with $\mathrm{HCl}: \mathrm{HNO}_{3} 3: 1$ in a PTFS high pressure system.

CMR*: Reference material treated with $\mathrm{HCl}: \mathrm{HNO}_{3}: \mathrm{HF} / \mathrm{H}_{3} \mathrm{BO}_{3}$ in a high pressure system.

$\mathrm{CMR}^{* *}$ : Certified concentration of reference material.

Table 3. Extractable arsenic concentration $\left(\mathrm{mg} \mathrm{kg}^{-1}\right.$ dry wt, mean \pm S.D., $\left.\mathrm{n}=6\right)$ in sediment lagoons from Huasco and Coposa salt flats, Chilean Altiplano.

\begin{tabular}{|c|c|c|c|c|c|c|c|c|}
\hline Sample & $\mathrm{H}_{2} \mathrm{O}$ & $\begin{array}{c}\text { NaOAc/ } \\
\text { HOAc }(1: 25)\end{array}$ & $\begin{array}{c}\mathrm{NaOAc} / \mathrm{HOAc} \\
(1: 50)\end{array}$ & $\begin{array}{l}\mathrm{NaOAc/HOAc} \\
\qquad(1+2)^{*}\end{array}$ & $\begin{array}{c}\left(\mathrm{NH}_{4}\right)_{2} \mathrm{C}_{2} \mathrm{O}_{4} \\
\quad / \mathbf{H}_{2} \mathbf{C}_{2} \mathbf{O}_{4}\end{array}$ & $\begin{array}{l}0.25 \mathrm{M} \\
\mathrm{H}_{2} \mathrm{SO}_{4}\end{array}$ & 0.11M HOAc & 0.43M HOAc \\
\hline $\mathrm{H} 01$ & $3.6 \pm 0.1$ & $34 \pm 2$ & $89 \pm 3$ & $73 \pm 2$ & $82 \pm 2$ & $125 \pm 3$ & $47 \pm 5$ & $121 \pm 1$ \\
\hline H08 & $30 \pm 1$ & $92 \pm 3$ & $89 \pm 4$ & $139 \pm 3$ & $162 \pm 7$ & $174 \pm 5$ & $87 \pm 3$ & $266 \pm 3$ \\
\hline $\mathrm{H} 12$ & $13 \pm 1$ & $35 \pm 1$ & - & - & - & $185 \pm 5$ & - & - \\
\hline $\mathrm{C} 01$ & $1.11 \pm 0.05$ & $11.7 \pm 0.5$ & $26 \pm 2$ & $24 \pm 1$ & $16.3 \pm 0.5$ & $41 \pm 2$ & $9.3 \pm 1$ & $44 \pm 1$ \\
\hline $\mathrm{C} 12$ & $0.88 \pm 0.01$ & $9.5 \pm 0.5$ & - & $23 \pm 1$ & - & $37 \pm 2$ & - & - \\
\hline
\end{tabular}

*: double extraction in the ratio of 1 to 25 
Table 4. Extractable manganese concentration $\left(\mathrm{mg} \mathrm{kg}^{-1}\right.$ dry wt, mean \pm S.D., $\left.\mathrm{n}=6\right)$ in sediment lagoons from Huasco and Coposa salt flats, Chilean Altiplano.

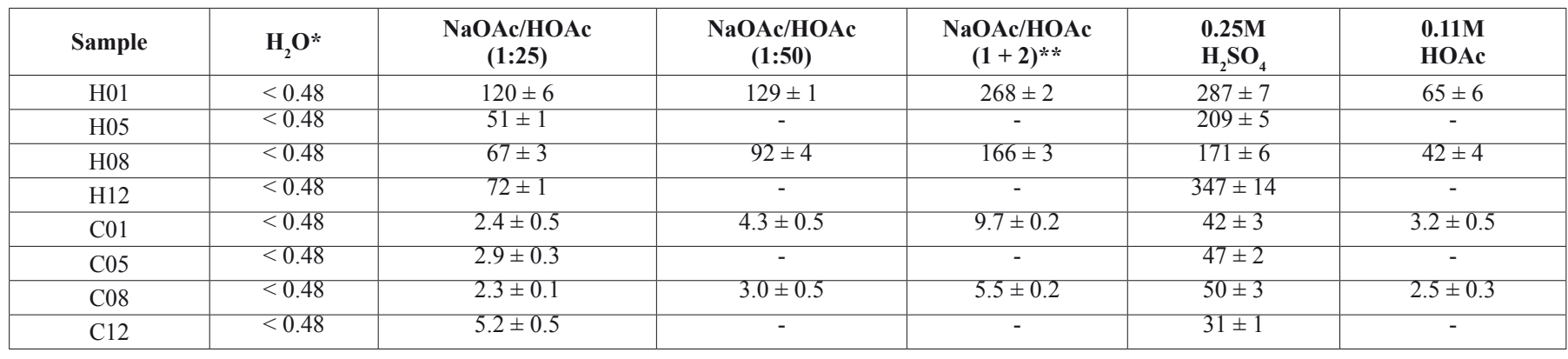

*: quantification limit (mg kg-1 dry wt)

$* *$ : double extraction in the ratio of 1 to 25 .

\section{CONCLUSION}

Lagoon sediments in both salt flats have the peculiarity of containing more than $50 \%$ of $\mathrm{CaCO}_{3}$ and high levels of arsenic. In Huasco, concentrations of metals and metalloids are significantly higher than those in Coposa, especially As and Mn. Concentrations of Fe, Mn and $\mathrm{Cr}$ present low levels in comparison with the average values found in limestone sediments (and other types of sediments). However, when compared with limestone sediments, the concentrations of $\mathrm{Zn}, \mathrm{Cu}$ and $\mathrm{Sb}$ are similar, but the concentrations of As and Se are much higher. The concentration of metalloids increases during a high evaporation season, whereas the concentration of metals displays different behaviors that depend on each element, season and the salt flat. Arsenic is very available and presents a high mobility, something which is not possible to observe in Mn. This, is because a fraction of the As found in sediments lies first, in the form of soluble salts, probably $\mathrm{Na}_{2} \mathrm{HAsO}_{4}$ second, it is associated to the calcium carbonate phase probably co-precipitated in the form of $\mathrm{CaHAsO}_{4}$ and, third, that it is also adsorbed into $\mathrm{Fe}$ and $\mathrm{Al}$ oxides within the sediments. On the other hand, in dry sediments, Mn would be found linked to insoluble compounds such as $\mathrm{MnCO}_{3}$ and $\mathrm{MnO}_{2}$.

There is a linear relationship between As concentration extracted with different solutions and total concentration of As found in sediments. The metalloid's mobility is similar in both ecosystems, however, under acidic and reducing conditions, the As mobility is higher in Huasco than Coposa. The percentage of extracted $\mathrm{Mn}$ from Huasco sediments is much higher than the one extracted from Coposa sediments. In both ecosystems, the extraction of As with $0.43 \mathrm{M}$ acetic acid and $0.25 \mathrm{M}$ sulfuric acid from sediments is $100 \%$ quantitative, which shows that As in sediments is mostly linked to $\mathrm{Ca}, \mathrm{Fe}$ and/ or $\mathrm{Mn}$. On the other hand, in the sediments found in Coposa the percentages of $\mathrm{Mn}$ extracted with $0.25 \mathrm{M}$ sulfuric acid are higher than those in Huasco, which confirms that in Coposa, $\mathrm{Mn}$ found in dry sediments is mostly as $\mathrm{MnO}_{2}$ insoluble.

\section{ACKNOWLEDGEMENTS}

Venecia Herrera would like to express her gratitude to Arturo Prat University for the facilities given in order to carry out Graduate studies which are sponsored by the Doctoral Program in Sciences of the Institute of Chemistry, Faculty of Mathematics and Basic Sciences, of the Pontifical Catholic University of Valparaíso, Chile. We would also like to express our sincere appreciation to Christopher Green for his significant contribution to the English translation of the original text.

\section{REFERENCES}

1.- G. Chong, Earth Sci. 17, 137, (1988)

2.- F. Squeo, B. Warner, R. Aravena, D. Espinoza, Rev. Chil. Hist. Nat. 79, 245, (2006)

3.- A.C.M. Bourg in Aquatic Ecotoxicology: Fundamental Concepts and Methodologies. Adsorption of Trace Inorganic and Organic Contaminants by Solid Particulate Matter, A. Boudou and F. Ribeyre eds. CRC Press, Inc. Boca Raton, Florida, 1989; pp.107-148.

4.- M. Leybourne, E. Cameron, Chem. Geol. 247, 208, (2008)

5.- P. Smedley, D. Kinniburgh, Appl. Geochem. 17, 517, (2002)

6.- F. Risacher, H. Alonso, C. Salazar, Earth-Sci. Rev. 63, 249, (2003)

7.- P. Campbell, A. Tessier in Aquatic Ecotoxicology: Fundamental Concepts and Methodologies. Geochemistry and Bioavailability of Trace Metals in Sediments. A. Boudou and F. Ribeyre eds. CRC Press, Inc. Boca Raton, Florida, 1989; pp. 125-128.

8.- C. Davison, R. Thomas, S. Mcvey, R. Perala, D. Littlejohn, A. Ure, Anal. Chim. Acta. 291, 277, (1994)

9.- C. Jain, D. Malik, R. Yadav, Environ. Monit. Assess. 130, 129, (2007)

10.- A. Tessier, P. Campbell, M. Bisson, Anal. Chem. 51 (7), 844, (1979)

11.- Ph. Quevauviller, Fresen. J. Anal. Chem. 354, 515, (1996)

12.- Ph. Quevauviller, Trac-Trend Anal. Chem. 17 (5), 289, (1998)

13.- M. Pueyo, G. Rauret, J. Bacon, A. Gomez, H. Muntau, Ph Quevauviller, J. López-Sánchez, J. Environ. Monitor. 3, 238, (2001)

14.- Ph. Quevauviller, A. Ure, H. Muntau, B. Griepink, Int. J. Environ. An. Ch. 51, 129, (1993)

15.- J. Kubová, P. Matús, M. Bujdos, I. Hagarová, J. Medved, Talanta 75, 1110, (2008)

16.- F. Risacher, B. Fritz, Geochim. Cosmochim. Ac. 155, 687, (1991a)

17.- D. Banks, H. Markland, P. Smith, C. Mendez, J. Rodríguez, A. Huerta, O. Saether, J. Geochem. Explor. 84, 141, (2004).

18.- S. Hill, J. Dawson, J. Price, I. Shuttler, C. Smith, J. Tyson, J. Anal. Atom. Spectrom. 14, 1245, (1999)

19.- M. Hoening, Talanta 54, 1021, (2001)

20.- I. De Gregori, H. Pinochet, M. Arancibia, A. Vidal, B. Environ. Contam. Tox. $57,163,(1996)$

21.- H. J. M. Bowen. Environmental Chemistry of the Elements. London: Academic Press; 1979.

22.-H. Faeah, W. Pickering, Chem. Spec. Bioavailab. 5(3), 81, (1993)

23.- M. I. Rivara, M. Cebrián, G. Corey, M. Hernández, I. Romieu, Toxicol. Ind. Health. 13, 2/3, 321, (1997)

24.- A. Smith, A. Arroyo, D. Mazumder, M. Kosnett, A. Hernandez, M. Beeris, M. Smith, L. Moore, Environ. Health Persp. 108, 617, (2000)

25.- C. Gleyzes, S. Tellier, R. Sabrier, M. Astruc, Environ. Technol. 22, 27, (2001)

26.- P. Kavanagh, M. Farago, I. Thornton, R Braman, Chem. Spec. Bioavailab. 9(3), 77, 1997

27.- W. Wenzel, N. Kirchbaumer, T. Prohaska, G. tingeder, E. Lombi, D. Adriano, Anal. Chim Acta. 436, 309, (2001)

28.- K. Gauthreaux, C. Hardaway, T. Falgoust, C. Noble, J. Sneddon, M. Beck, J. Beck, J. Environ. Monitor. 3, 487 (2001) 